Bull. Fac . Agric., Cairo Univ., 69: 177-188. (2018).

\title{
PERFORMANCE OF THE RICE VARIETY EGYPTIAN HYBRID-1 UNDER DIFFERENT LEVELS OF PHOSPHORUS FERTILIZER AND ORTHOPHOSPHORIC ACID AS FOLIAR SPRAY
}

(Received:26.7.2018)

\author{
By \\ E. E. Gewaily

\begin{abstract}
Rice Research and Training Center, Field Crops Research Institute, Agricultural Research Center, Sakha - Kafr El-Sheikh, Egypt.
\end{abstract}

\begin{abstract}
A field experiment was conducted in 2014 and 2015 consecutive seasons at the farm of Sakha Agricultural Research Station, Kafr El-Sheikh, Egypt to study the performance of the variety rice Egyptian hybrid-1 (EHR1) under different phosphorus fertilizer levels, i.e. control (P1), 18 (P2), 36 (P3) and $54(\mathrm{P} 4) \mathrm{Kg} \mathrm{P}_{2} \mathrm{O}_{5}$ ha $^{-1}$ and $2 \%$ orthophosphoric acid as foliar spray. The treatments were applied at different periods, namely control (without foliar spray) (F1), foliar spray with $2 \%$ of orthophosphoric acid at mid tillering (MT) period (F2), at late booting (LB) period (F3) and at MT + LB periods (F4). The experimental design was split plot where the main plots were arranged in randomized complete blocks with four replications. The phosphorus levels were allocated in the main plots, while sub-plots were received foliar applications with $2 \%$ orthophosphoric acid $\left(\mathrm{H}_{3} \mathrm{PO}_{4}\right)$. The studied characters plant height, number of tillers hill $^{-1}$, panicle length, panicle weight, number of panicles hill ${ }^{-1}$, number of filled grains panicle ${ }^{-1}$, number of unfilled grains panicle ${ }^{-1}, 1000$-grain weight, grain yield $\mathrm{tha}^{-1}$, straw yield $\mathrm{tha} \mathrm{h}^{-1}$ and phosphorus uptake $\mathrm{kg} \mathrm{ha}^{-1}$. All studied characters increased with all treatment as compared with the control. Application of either 36 or $54 \mathrm{~kg} \mathrm{P}_{2} \mathrm{O}_{5}$ ha $^{-1}$ gave the same highest values of the studied characters except empty grains panicle ${ }^{-1}$ which reached the maximum under the control. A significant increase in each of plant height $(\mathrm{cm})$, number of tillers hill ${ }^{-1}$, number of panicles hill ${ }^{-1}$, panicle weight, panicle length, number of filled grains panicle ${ }^{-1}$, grain and straw yields and P uptake was observed in both seasons. Spray of the tested cultivar with $2 \%$ orthophosphoric acid at MT or at MT plus LB gave the greatest values for all studied characters, except the F3 treatment (spray one time at late booting) which gave the least as compared to the other sprayed treatments because the plant had the required amount at this time. The results revealed that the combination of 36 or $54 \mathrm{~kg} \mathrm{P}_{2} \mathrm{O}_{5} \mathrm{ha}^{-1}$ along with foliar $2 \% \mathrm{H}_{3} \mathrm{PO}_{4}$ at MT (mid tillering) treatment produced the same greatest values of grain yield and most of growth and yield attributes without any significant difference between them. From economical point of view, the combination of $36 \mathrm{~kg} \mathrm{P}_{2} \mathrm{O}_{5}$ ha $^{-1}$ with $2 \% \mathrm{H}_{3} \mathrm{PO}_{4}$ sprayed at MT was the best combination because it produced the highest grain yield and saved one third of phosphorus fertilizer.
\end{abstract}

Key words: Oryza sativa L., phosphorus fertilizer, foliar application

\section{INTRODUCTION}

Maximizing and sustaining crop yields are main objectives to enhance yield production. One of the major problems constraining the development of an economically successful agriculture is nutrient deficiency (Fageria and Baligar, 2005). After nitrogen, phosphorus (P) has more widespread influence on both natural and agricultural ecosystems than any other essential plant elements (Brady and Weil, 2002). Higgs et al.(2000) reported that 30 to $50 \%$ of the increase in world food production since the
1950 's is attributable to fertilizer use, including $P$ use. Phosphorus deficiency in crop plants is a widespread problem in various parts of the world, especially in highly weathered soils, as well as calcareous/alkaline soils (Fageria and Baligar, 2001 and Faye et al., 2006). Worldwide applications of phosphate fertilizers now exceed over 30 million metric tons annually (Epstein and Bloom, 2005). The deficiency of this element is related to several factors. These factors are low natural level in some soils, high immobile or fixation capacity of soils, and 
uptake of modern crop cultivars in large amounts, loss by soil erosion, and use of low rate by farmers in developing countries.

Phosphorus is an essential constituent of adenosine triphosphate (ATP), nucleotides, nucleic acids, and phospholipids. Its major functions are in energy storage and transfer and membrane integrity. It is mobile within the plant and promotes tillering, root development, early flowering, and ripening (especially where the temperature is low). It is particularly important in the early growth stages. The addition of mineral $\mathrm{P}$ fertilizer is required when rice root system is not yet fully developed and the native soil $\mathrm{P}$ supply is little. $\mathrm{P}$ is remobilized within the plant during later growth stages if sufficient $\mathrm{P}$ has been absorbed during early growth (Doberman and Fairhruse, 2000). The timing of $\mathrm{P}$ fertilizer application may need to be changed to maximize crop use of the $\mathrm{P}$ fertilizer and avoid possible $\mathrm{P}$ deficiency. Knowledge of how rice responds to the $\mathrm{P}$ fertilizer application time during the growing season is essential for the development of efficient $P$ fertilizer recommendations (Slaton et al., 2002). Cahyono and Hartati (2013) reported that improving the efficiency of $\mathrm{P}$ fertilizer can be reached by providing a quickly dissolving phosphate fertilizer. However, as phosphate forms a reaction with other compounds soon after release from the fertilizer, a proper method of $\mathrm{P}$ application, split application, should be applied. Girma et al. (2007) reported that foliar application is a visible economic way to supplement the plant nutrients for more efficient fertilization. Foliar application of phosphorus could be used as an efficient phosphorus management tool in cereal crops when applied at appropriate growth stages and rates. Zayed (2012) reported that P application in basal and foliar combination at various growth stages significantly increases nutrient leaf content, plant height, tiller number hill ${ }^{-1}$, and improves rice grain yield and its components. Barker and Pilbeam (2007) reported that among the various organic and inorganic phosphorus-containing compounds on vegetable crops, foliar spray with orthophosphoric acid was the most effective.

The objectives of the current study were to evaluate the effect of $\mathrm{P}$ fertilizer application level and the time of foliar spray applications with $2 \%$ orthophosphoric acid at different growth stages and their interaction on grain yield and $\mathrm{P}$ uptake of the Egyptian hybrid rice one (EHR1) variety.

\section{MATERIALS AND METHODS}

A field experiment was conducted during the two consecutive seasons 2014 and 2015 rice growing seasons at the farm of Sakha Agricultural Research Station, Kafr El-Sheikh, Egypt. The experiment was conducted to study the effect of three times of foliar spray applications with $2 \%$ orthophosphoric acid plus control under four phosphorus levels and their interaction on growth and yield and its component of the Egyptian hybrid rice one (EHR1) variety under transplanting method. The preceding crop was barely (Hordeum Vulgare L.) in the two seasons. The soil of the experimental site is clayey in texture. The initial soil chemical properties at $0-$ to $20 \mathrm{~cm}$ soil depth of the experimental site were: $\mathrm{pH} 8.3$, organic matter (OM) $1.5 \%$, total nitrogen $475 \mathrm{mg}$ $\mathrm{kg}^{-1}$, available P $10 \mathrm{mg} \mathrm{kg}^{-1}$, available K $360 \mathrm{mg}$ $\mathrm{kg}^{-1}$, available $\mathrm{Zn} 0.70 \mathrm{mg} \mathrm{kg}^{-1}$, available Fe 5.20 $\mathrm{mg} \mathrm{kg}{ }^{-1}$ and available $\mathrm{Mn} 2.9 \mathrm{mg} \mathrm{kg}^{-1}$. The experimental design was split plot in randomized complete blocks arrangement with four replications. The main plots were assigned to four P fertilizer levels (soil application), while the sub-plots were assigned to four foliar application treatments with $2 \%$ orthophosphoric acid $\mathrm{H}_{3} \mathrm{PO}_{4}$ (assay $70 \%$, density $1.60 \mathrm{~g} \mathrm{~cm}^{-3}$ and $\mathrm{P}$ content $354 \mathrm{gm} \mathrm{l}^{-1}$ ). Phosphorus fertilizer application at four levels i.e. control (without any phosphorus fertilizer) (P1), 18 (P2), 36 (P3) and $54(\mathrm{P} 4) \mathrm{kg} \mathrm{P}_{2} \mathrm{O}_{5} \mathrm{ha}^{-1}$ in the form of single superphosphate $\left(\begin{array}{lll}15 \% & \mathrm{P}_{2} \mathrm{O}_{5}\end{array}\right)$ was used and applied as a basal at the time of final land preparation and merely incorporated into the soil. The four foliar application treatments were: control (without any of orthophosphoric acid) (F1), foliar spray with $2 \%$ of orthophosphoric acid at mid tillering (MT) period (F2), foliar spray with $2 \%$ of orthophosphoric acid at late booting (LB) (F3), foliar spray with $2 \%$ of orthophosphoric acid at MT + LB (F4). The amount of water for each plot for dissolving orthophosphoric acid was calculated based on 5001 water ha ${ }^{-1}$. Seeds at the rate of $24 \mathrm{~kg} \mathrm{ha}^{-1}$ were soaked in water for $24 \mathrm{hr}$, and then incubated for $48 \mathrm{hr}$ to hasten early germination. Pre-germinated seeds were uniformly broadcasted in the nursery on $5^{\text {th }}$ and $9^{\text {th }}$ May of the two seasons, respectively. The permanent field was well prepared, i.e. plowed twice followed by good dry leveled and immediately irrigation and slight leveling were done. Seedlings were carefully uprooted from the nursery after 30 days from sowing and distributed through the plots. 
Seedlings were manually transplanted into $12 \mathrm{~m}^{2}$ subplots in 20x20 cm space between rows and hills, with 3 seedlings hill ${ }^{-1}$. Nitrogen fertilizer was applied at the rate of $165 \mathrm{~kg} \mathrm{~N} \mathrm{ha}^{-1}$ in the form of Urea $(46.5 \% \mathrm{~N})$. Urea was added in three equal splits (at basal application before transplanting, 30 and 60 days after transplanting). All plots received $48 \mathrm{~kg} \mathrm{~K}_{2} \mathrm{O}$ ha $^{-1}$ as basal dose in the form of Potassium Sulphate. All other agronomic practices were done as recommended. Plant samples (five hills each) were taken randomly from each plot five days before harvest to estimate the plant height $(\mathrm{cm})$, number of tillers hill $^{-1}$ and number of panicles hill ${ }^{-1}$. Ten panicles were collected randomly to estimate the panicle length $(\mathrm{cm})$, panicle weight $(\mathrm{g})$, number of both filled and unfilled grains per panicle, and 1000grain weight. The crop of central $5 \mathrm{~m}^{2}$ of each plot was harvested separately at full maturity, dried, threshed, then grain and straw yields were recorded and each of them was converted into $t$ $\mathrm{ha}^{-1}$. The grain yield was adjusted at $14 \%$ moisture content. $\mathrm{P}$ content in the grain and straw was determined according to the method of Watanabe and Olsen (1965). Total P uptake in biological yield (grain plus straw) was calculated by multiplying $\mathrm{P}$ content with their grain and straw yield. The obtained data were subjected to analyses of variance according to Gomez and Gomez (1984) using the computer program (Genstat). The significantly different means were compared using LSD test.

\subsection{Growth}

\section{RESULTS AND DISCUSSION}

Means of plant height and number of tillers hill $^{-1}$ of hybrid rice cv. Hybrid 1 as affected by phosphorus levels and time of foliar applications with 2\% orthophosphoric acid in 2014 and 2015 are presented in Table (1). Plant height increased with increasing the rate of $\mathrm{P}$ fertilizer. Application of $54 \mathrm{~kg} \mathrm{P}_{2} \mathrm{O}_{5} \mathrm{ha}^{-1}$ produced the tallest plant and it was statistically at par with 36 $\mathrm{kg} \mathrm{P}_{2} \mathrm{O}_{5} \mathrm{ha}^{-1}$. The control (without phosphorus as basal application (P1)) produced the shortest plants. Increase in plant height due to $P$ application could be attributed to the positive role of $\mathrm{P}$ in the stimulation of cell division and elongation. These results are in harmony with those reported by Zayed (2012) and Naeem et al. (2016). The data also showed that in both seasons, foliar application with $2 \% \mathrm{H}_{3} \mathrm{PO}_{4}$ at mid tillering (MT) period produced the tallest plants, while the control treatment produced the shortest plants in the two studied seasons.
Table (1): Plant height and tiller number of the Egyptian Hybrid Rice1 variety as affected by phosphorus levels and time of foliar application.

\begin{tabular}{|c|c|c|c|c|}
\hline \multirow[t]{2}{*}{ Treatment } & \multicolumn{2}{|c|}{$\begin{array}{l}\text { Plant height } \\
\text { (cm) }\end{array}$} & \multicolumn{2}{|c|}{$\begin{array}{l}\text { No. of tillers } \\
\text { hill }^{-1}\end{array}$} \\
\hline & 2014 & 2015 & 2014 & 2015 \\
\hline P level ( basal) & & & & \\
\hline$\overline{\text { control }(\mathrm{P} 1)}$ & 86.54 & 87.42 & 28.38 & 26.08 \\
\hline $18 \mathrm{~kg} \mathrm{P}_{2} \mathrm{O}_{5} \mathrm{ha}^{-1}(\mathrm{P} 2)$ & 91.50 & 91.31 & 28.96 & 27.90 \\
\hline $36 \mathrm{~kg} \mathrm{P}_{2} \mathrm{O}_{5} \mathrm{ha}^{-1}(\mathrm{P} 3)$ & 91.80 & 92.59 & 31.58 & 30.83 \\
\hline $54 \mathrm{~kg} \mathrm{P}_{2} \mathrm{O}_{5} \mathrm{ha}^{-1}(\mathrm{P} 4)$ & 92.19 & 92.94 & 31.95 & 31.52 \\
\hline LSD 5\% & 0.79 & 0.73 & 0.75 & 0.77 \\
\hline$\underline{\mathrm{H}}_{3} \underline{\mathbf{P O}}_{4}$ foliar spray & & & & \\
\hline Without (F1) & 89.13 & 90.44 & 29.27 & 28.26 \\
\hline $2 \%$ at $\mathrm{MT}(\mathrm{F} 2)$ & 91.38 & 91.63 & 30.96 & 29.55 \\
\hline $2 \%$ at $\mathrm{LB}(\mathrm{F} 3)$ & 90.29 & 90.96 & 29.90 & 29.05 \\
\hline $2 \%$ at $\mathrm{MT}+\mathrm{LB}(\mathrm{F} 4)$ & 91.23 & 91.23 & 30.73 & 29.47 \\
\hline LSD 5\% & 0.84 & 0.54 & 0.38 & 0.37 \\
\hline Interaction & NS & $\mathrm{NS}$ & $*$ & $*$ \\
\hline
\end{tabular}

LB= late booting MT= mid tillering.

The number of tillers of EHR $1 \mathrm{cv}$. significantly varied due to the different levels of phosphorus as basal application in both seasons (Table 1). Application of $54 \mathrm{~kg} \mathrm{P}_{2} \mathrm{O}_{5} \mathrm{ha}^{-1}$ gave the highest number of tillers, but was statistically at par with $36 \mathrm{~kg} \mathrm{P}_{2} \mathrm{O}_{5} \mathrm{ha}^{-1}$ in the two studied seasons. Plants grown without phosphorus (control) had the lowest number of tillers hill ${ }^{-1}$. It might be due to the role of $\mathrm{P}$ for enhancing the upground nodes to immerge more tillers. These findings are in agreement with those of Matsou et al. (1995), who reported that applying much $\mathrm{P}$ fertilizers is necessary to help rice plants to accelerate the phosphate absorption for increased tillering. Naeem et al. (2016) reported that $\mathrm{P}$ application increased the content of phosphorus leaf, which led to high ATP, NAD and NAPH that improve plant metabolism resulting in high relative growth rate and more tillers and bud formation. A similar trend was found by Alam et al. (2009) and Metwally et al. (2012). Number of tillers hill ${ }^{-1}$ was also significantly affected by application of foliar spray treatments (Table 1). Foliar application with $2 \% \quad \mathrm{H}_{3} \mathrm{PO}_{4}$ at mid tillering (MT) period in the F2 treatment produced the peak number of tillers hill ${ }^{-1}$ without any significant differences with foliar spray with $2 \% \mathrm{H}_{3} \mathrm{PO}_{4}$ at mid tillering (MT) plus late booting (LB) in the treatment F4 in the two studied seasons. The plants untreated with $\mathrm{H}_{3} \mathrm{PO}_{4}$ foliar spray produced the lowest number of tillers hill ${ }^{-1}$ in both seasons. Interaction between $\mathrm{P}$ fertilizer levels and time of foliar spray significantly affected the number of tillers hill $^{-1}$ (Table 2). The treatment of $\mathrm{P} 4\left(54 \mathrm{~kg} \mathrm{P}_{2} \mathrm{O}_{5}\right.$ 
Table (2): Tiller number of the Egyptian Hybrid Rice1 variety as affected by the interaction between phosphorus levels and time of foliar application.

\begin{tabular}{|c|c|c|c|c|c|c|c|c|}
\hline \multirow{2}{*}{$\mathrm{P}_{2} \mathrm{O}_{5} \mathrm{~kg} \mathrm{ha}^{\mathrm{H}_{3} \mathrm{PO}_{4} \text { foliar }}$} & \multicolumn{4}{|c|}{2014} & \multicolumn{4}{|c|}{2015} \\
\hline & F1 & F2 & F3 & F4 & F1 & F2 & F3 & F4 \\
\hline control (P1) & 27.75 & 28.50 & 28.17 & 29.09 & 26.06 & 26.25 & 25.92 & 26.11 \\
\hline $18(\mathrm{P} 2)$ & 28.33 & 29.42 & 29.00 & 29.09 & 27.42 & 28.22 & 27.92 & 28.03 \\
\hline 36 (P3) & 30.22 & 32.89 & 30.89 & 32.30 & 29.45 & 31.50 & 30.86 & 31.53 \\
\hline $54(\mathrm{P} 4)$ & 30.78 & 33.03 & 31.53 & 32.45 & 30.12 & 32.25 & 31.50 & 32.22 \\
\hline LSD $5 \%$ & \multicolumn{4}{|c|}{0.69} & \multicolumn{4}{|c|}{0.95} \\
\hline
\end{tabular}

F1= without foliar, F2= foliar $2 \% \mathrm{H}_{3} \mathrm{PO}_{4}$ at MT, F3= foliar $2 \% \mathrm{H}_{3} \mathrm{PO}_{4}$ at $\mathrm{LB}$ and $\mathrm{F} 4=$ foliar $2 \% \mathrm{H}_{3} \mathrm{PO}_{4}$ at MT+LB.

$\mathrm{ha}^{-1}$ ) combined with F2 treatment (foliar spray with $2 \% \mathrm{H}_{3} \mathrm{PO}_{4}$ at $\mathrm{MT}$ ) produced the highest number of tillers hill ${ }^{-1}$ in both seasons which was statistically similar with values of $\mathrm{P} 3 \mathrm{~F} 2$ and $\mathrm{P} 4 \mathrm{~F} 4$ in the first season, and with $\mathrm{P} 3 \mathrm{~F} 2, \mathrm{P} 3 \mathrm{~F} 4$ and P4F4 in the second one. The lowest number of tillers hill ${ }^{-1}$, however, was produced by the treatment P1F1. Doberman and Fairhruse (2000) reported that $\mathrm{P}$ is mobile within the plant and promotes tillering, root development, early flowering, and ripening. It is particularly important when $\mathrm{P}$ is applied at early growth stages. The addition of mineral $\mathrm{P}$ fertilizer is required when the rice root system is not yet fully developed.

\subsection{Yield attributes}

Means of panicle length, panicle weight and panicle numbers hill ${ }^{-1}$ of EHR 1 as affected by phosphorus levels and time of foliar application in 2014 and 2015 are presented in (Table 3).

Phosphorus basal applied caused a significant increase in panicle length as compared with control (Table 3). Application of $54 \mathrm{~kg} \mathrm{P}_{2} \mathrm{O}_{5} \mathrm{ha}^{-1}$ produced the longest panicles without significant differences with the application of $36 \mathrm{~kg} \mathrm{P}_{2} \mathrm{O}_{5} \mathrm{ha}^{-1}$ in the two studied seasons. These findings are in line with those of Alam et al. (2009), who reported that the higher the levels of $\mathrm{N}$, the longer the panicle although panicle increase was not proportional to the increase in the level of $\mathrm{P}$ fertilizer. The data also showed that, in both seasons, the untreated control plants (P1) gave the shortest panicle. These results are in agreement with those of Sahar and Burbey (2003), and Metwally et al. (2012). Application of foliar spray treatments and their interaction did not show any significant variation in respect of panicle length in both seasons.

The tested $\mathrm{P}$ basal treatments significantly affected panicle weight in both seasons under study (Table 3). Plants fertilized with either level of phosphorus fertilizer significantly gave heavier panicle weight than the unfertilized ones.
In both seasons, plants fertilized with either 36 or $54 \mathrm{~kg} \mathrm{P}_{2} \mathrm{O}_{5}$ ha $^{-1}$ gave the heaviest panicles. The lightest panicles were obtained in the absence of $\mathrm{P}$ application. Application of $\mathrm{P}$ fertilizer resulted in ensuring high ATP, which provided high photosynthesis resulted in more assimilates in pre and post heading, which lead to improve panicle filling and consequently increase in weight of panicle. These data are in agreement with those obtained by Sahar and Burbey (2003), Metwally et al., (2012) and Naeem et al., (2016).

Significant variation in panicle weight was observed due to application of foliar spray treatments in the first season (Table 3). Spraying the tested variety with $2 \% \quad \mathrm{H}_{3} \mathrm{PO}_{4}$ at $\mathrm{MT}$ recorded the heaviest panicles as compared with the other foliar treatments. In the second season, there were no significant differences among all the foliar spray treatments. Interaction between $P$ fertilizer basal applied in dry soil and $\mathrm{P}$ applied as foliar spray $2 \%$ orthophophoric acid did not show any significant variation in respect of panicle weight in both seasons.

The number of panicles hill ${ }^{-1}$ gradually increased with the increase of phosphorus levels up to $54 \mathrm{~kg} \mathrm{P}_{2} \mathrm{O}_{5}$ ha $^{-1}(\mathrm{P} 4)$ (Table 3). Application of $54 \mathrm{~kg} \mathrm{P}_{2} \mathrm{O}_{5} \mathrm{ha}^{-1}$ produced the maximum number of panicles hill ${ }^{-1}$ followed by the application of $36 \mathrm{~kg} \mathrm{P}_{2} \mathrm{O}_{5}$ ha $^{-1}$ treatment. As for foliar spray and its effect on the number of panicles hill ${ }^{-1}$, data indicated that each of the foliar spray treatments caused an increase in the number of panicles as compared with the control. The highest number of panicles hill ${ }^{-1}$ were found when the tested variety was sprayed at MT (F2) followed by F4 treatment (sprayed at both MT and LB). It could be attributed mainly to $\mathrm{P}$ application before planting which, encourage the aboveground nodes to emerge early and effective tillers as well as the role of $\mathrm{P}$ for increasing the flowering hormones (phytocrom) which increase the number of panicles during panicle initiation, besides 
Table (3): Panicle length, panicle weight and the number of panicle hill ${ }^{-1}$ of the Egyptian Hybrid Rice1 variety as affected by phosphorus levels and the time of foliar application.

\begin{tabular}{|c|c|c|c|c|c|c|}
\hline \multirow[t]{2}{*}{ Treatment } & \multicolumn{2}{|c|}{$\begin{array}{c}\text { Panicle length } \\
(\mathrm{cm})\end{array}$} & \multicolumn{2}{|c|}{ Panicle weight (g) } & \multicolumn{2}{|c|}{ No. of panicles hill ${ }^{-1}$} \\
\hline & 2014 & 2015 & 2014 & 2015 & 2014 & 2015 \\
\hline P level (basal) & & & & & & \\
\hline $\begin{array}{l}\text { control }(\mathrm{P} 1) \\
\text {. }\end{array}$ & 22.90 & 21.81 & 3.88 & 3.98 & 26.38 & 24.58 \\
\hline $18 \mathrm{~kg} \mathrm{P}_{2} \mathrm{O}_{5} \mathrm{ha}^{-1}(\mathrm{P} 2)$ & 23.73 & 22.30 & 4.24 & 4.19 & 27.46 & 25.90 \\
\hline $36 \mathrm{~kg} \mathrm{P}_{2} \mathrm{O}_{5} \mathrm{ha}^{-1}(\mathrm{P} 3)$ & 23.74 & 23.04 & 4.47 & 4.31 & 29.11 & 28.58 \\
\hline $54 \mathrm{~kg} \mathrm{P}_{2} \mathrm{O}_{5} \mathrm{ha}^{-1}(\mathrm{P} 4)$ & 23.77 & 23.41 & 4.46 & 4.34 & 29.92 & 28.77 \\
\hline LSD 5\% & 0.34 & 0.43 & 0.13 & 0.17 & 0.25 & 0.77 \\
\hline$\underline{\mathrm{H}}_{3} \underline{\mathbf{P O}}_{4} \underline{\text { foliar spray }}$ & & & & & & \\
\hline Without (F1) & 22.50 & 22.61 & 4.14 & 4.19 & 27.33 & 26.14 \\
\hline $2 \%$ at $\mathrm{MT}(\mathrm{F} 2)$ & 23.78 & 22.83 & 4.41 & 4.26 & 29.02 & 27.43 \\
\hline $2 \%$ at LB (F3) & 23.54 & 22.55 & 4.25 & 4.18 & 27.96 & 26.92 \\
\hline $2 \%$ at $\mathrm{MT}+\mathrm{LB}(\mathrm{F} 4)$ & 23.31 & 22.58 & 4.24 & 4.19 & 28.55 & 27.35 \\
\hline LSD 5\% & NS & NS & 0.14 & NS & 0.38 & 0.37 \\
\hline Interaction & NS & NS & NS & NS & $*$ & $*$ \\
\hline
\end{tabular}

MT=Mid tillering $\mathbf{L B}=$ Late booting

improving panicle growth rate including the number of branches and spikelets. A similar trend was found by Sahar and Burbey (2003), Alam et al. (2009) and Metwally et al.(2012). Significant variation in the number of panicles hill $^{-1}$ of EHR1 was observed due to the interaction between $\mathrm{P}$ fertilizer as soil application and foliar spray with $2 \% \mathrm{H}_{3} \mathrm{PO}_{4}$ treatments (Table 4). The combination of $\mathrm{P} 4$ with F2 treatments produced the maximum values of number of panicles hill ${ }^{-1}$ which was statistically at par with $\mathrm{P} 3 \mathrm{~F} 2$ and P4F4 in the first season and with $\mathrm{P} 3 \mathrm{~F} 2, \mathrm{P} 3 \mathrm{~F} 4$ and $\mathrm{P} 4 \mathrm{~F} 4$ in the second season. The minimum number of panicles hill ${ }^{-1}$ was recorded when no $\mathrm{P}$ fertilizer was added. The combination of $\mathrm{P} 3$ with each of F2 and F4 caused a continuous P supply for the tested cultivar through its different stages, that causes an increase in all biological and physiological processes, especially photosynthesis which increase the number of panicles and other components of yield. Doberman and Fairhruse (2000) reported that P is remobilized within the plant during later growth stages if sufficient $\mathrm{P}$ has been absorbed during early growth.

The number of filled grains panicle ${ }^{-1}$, the number of unfilled grains panicle ${ }^{-1}$ and 1000grain weight as influenced by phosphorus fertilizer as basal application and orthophosphoric acid as foliar spray are presented in Table (5). Data indicated that basal application of phosphorus fertilizer caused a significant increase in filled grains panicle ${ }^{-1}$ as compared with control. The greatest number of

grains was found when either 36 or $54 \mathrm{~kg} \mathrm{P}_{2} \mathrm{O}_{5}$ $\mathrm{ha}^{-1}$ was applied without any significant difference between them. It might be due to the continuous supply of adequate amount of phosphorus for the tested rice cultivar during its different stages that increases the biological and physiological process such as ATP, NAD, and NADP which enhance and increase the photosynthesis and its assimilates consequently increase the filling process. These results are in agreement with those reported by Sahar and Burbey (2003), Alam et al. (2009) and Metwally et al. (2012). As for foliar spray with $2 \%$ orthophosphoric acid, data revealed that spraying the EHR1 cultivar with $2 \%$ orthophosphoric acid at any of the tested periods caused an increase in the number of filled grains as compared with the control. The highest number of filled grains was observed when the plants were sprayed at MT without any significant difference with the spraying at MT plus LB in the first season, while in the second season only spraying at mid tilliring (MT) produced the highest value in this aspect. The decrease in grain filling numbers under spraying by $2 \%$ orthophosphoric acid at late booting might be due to the presence of the required amount of phosphorus at filling period, resulting in low response under this treatment (F3).

Data in Table (6) clarified that there was a significant difference among the interaction treatments. The combination of each foliar spray treatments with any level of phosphorus 
Table (4): Panicles number hill $^{-1}$ of the Egyptian Hybrid Rice1 variety as affected by the interaction between phosphorus levels and the time of different foliar application.

\begin{tabular}{|c|c|c|c|c|c|c|c|c|}
\hline \multirow{2}{*}{$\begin{array}{r}\mathrm{H}_{3} \mathrm{PO}_{4} \text { foliar } \\
\mathrm{P}_{2} \mathrm{O}_{5} \mathrm{~kg} \mathrm{ha}^{-1}\end{array}$} & \multicolumn{4}{|c|}{2014} & \multicolumn{4}{|c|}{2015} \\
\hline & F1 & F2 & F3 & F4 & F1 & F2 & F3 & F4 \\
\hline $\begin{array}{ll}0 & (\mathrm{P} 1) \\
\end{array}$ & 25.75 & 26.50 & 26.17 & 27.09 & 24.56 & 24.75 & 24.42 & 24.61 \\
\hline $18(\mathrm{P} 2)$ & 26.83 & 27.92 & 27.50 & 27.59 & 25.42 & 26.22 & 25.91 & 26.03 \\
\hline $36(\mathrm{P} 3)$ & 28.00 & 30.67 & 28.67 & 29.09 & 27.20 & 29.25 & 28.61 & 29.28 \\
\hline $54(\mathrm{P} 4)$ & 28.75 & 31.00 & 29.50 & 30.42 & 27.37 & 29.50 & 28.75 & 29.47 \\
\hline LSD $5 \%$ & \multicolumn{4}{|c|}{0.67} & \multicolumn{4}{|c|}{0.73} \\
\hline
\end{tabular}

F1= without foliar, F2= foliar $2 \% \mathrm{H}_{3} \mathrm{PO}_{4}$ at MT, F3= foliar $2 \% \mathrm{H}_{3} \mathrm{PO}_{4}$ at $\mathrm{LB}$ and $\mathrm{F} 4=$ foliar $2 \% \mathrm{H}_{3} \mathrm{PO}{ }_{4}$ at $\mathrm{MT}+\mathrm{LB}$.

Table (5): Number of filled grains panicle ${ }^{-1}$, number of unfilled grains panicle ${ }^{-1}$ and 1000-grain weight of the Egyptian Hybrid Rice1 variety as affected by phosphorus levels and the time of foliar application.

\begin{tabular}{|c|c|c|c|c|c|c|}
\hline \multirow{2}{*}{ Treatment } & \multicolumn{2}{|c|}{ Filled grain panicle ${ }^{-1}$} & \multicolumn{2}{|c|}{ Unfilled grain panicle $^{-1}$} & \multicolumn{2}{|c|}{1000 grain weight $(\mathrm{g})$} \\
\hline & 2014 & 2015 & 2014 & 2015 & 2014 & 2015 \\
\hline $\begin{array}{l}\frac{\text { P level (basal) }}{\text { control (P1) }} \\
18 \mathrm{~kg} \mathrm{P}_{2} \mathrm{O}_{5} \mathrm{ha}^{-1}(\mathrm{P} 2) \\
36 \mathrm{~kg} \mathrm{P}_{2} \mathrm{O}_{5} \mathrm{ha}^{-1}(\mathrm{P} 3) \\
54 \mathrm{~kg} \mathrm{P}_{2} \mathrm{O}_{5} \mathrm{ha}^{-1}(\mathrm{P} 4)\end{array}$ & $\begin{array}{l}151.40 \\
163.64 \\
171.93 \\
172.94 \\
\end{array}$ & $\begin{array}{l}152.16 \\
159.64 \\
164.20 \\
166.42 \\
\end{array}$ & $\begin{array}{l}15.16 \\
14.14 \\
13.28 \\
11.71 \\
\end{array}$ & $\begin{array}{l}13.05 \\
12.62 \\
11.93 \\
10.67 \\
\end{array}$ & $\begin{array}{l}24.20 \\
24.71 \\
25.53 \\
25.50 \\
\end{array}$ & $\begin{array}{l}24.35 \\
24.93 \\
25.57 \\
25.54 \\
\end{array}$ \\
\hline LSD 5\% & 1.46 & 1.84 & 0.55 & 0.31 & 0.22 & 0.28 \\
\hline $\begin{array}{l}\underline{\mathrm{H}}_{3} \mathbf{P O}_{4} \text { foliar spray } \\
\text { Without (F1) } \\
2 \% \text { at } \mathrm{MT}(\mathrm{F} 2) \\
2 \% \text { at } \mathrm{LB}(\mathrm{F} 3) \\
2 \% \text { at } \mathrm{MT}+\mathrm{LB}(\mathrm{F} 4)\end{array}$ & $\begin{array}{l}161.39 \\
167.75 \\
164.33 \\
166.69 \\
\end{array}$ & $\begin{array}{l}157.60 \\
163.92 \\
159.80 \\
161.10 \\
\end{array}$ & $\begin{array}{l}15.19 \\
12.23 \\
14.20 \\
12.67 \\
\end{array}$ & $\begin{array}{l}13.44 \\
11.08 \\
12.61 \\
11.12 \\
\end{array}$ & $\begin{array}{l}24.70 \\
25.26 \\
24.80 \\
25.19 \\
\end{array}$ & $\begin{array}{l}24.81 \\
25.33 \\
24.95 \\
25.30 \\
\end{array}$ \\
\hline LSD 5\% & 1.23 & 1.49 & 0.62 & 0.34 & 0.26 & 0.36 \\
\hline Interaction & $*$ & NS & $*$ & $*$ & $*$ & $*$ \\
\hline
\end{tabular}

MT=Mid tillering $\mathbf{L B}=$ Late booting

fertilizer basal applied cased an increase in number of filled grains panicle ${ }^{-1}$ as compared with control. The greatest number of filled grains panicle ${ }^{-1}$ was observed when F2 treatment was combined with either P3 or P4 treatment. For economical point of view, the combination of F2 with P3 treatment was the best combination. The combination of F2 with P3 treatment makes continuous supply of adequate amount of phosphorus to the tested rice hybrid and improves the viability of flag leaf beside the second and third leaves which impact about 75 $\%$ from total photosynthesis and its products (assimilates). The assimilates or metabolites stream are translocated directly from flag leaf to the spikelets (from source to sink) and consequently increase the filling rate percentage, resulting in an increase in number of filled grains.

Number of unfilled grains panicle ${ }^{-1}$ of the Egyptian Hybrid Rice1 was significantly affected by basal application of P levels (Table 5). The plants fertilized with $54 \mathrm{~kg} \mathrm{P}_{2} \mathrm{O}_{5} \mathrm{ha}^{-1}$ produced the lowest number of unfilled grains in both seasons. While the plants that had no basal $P$ fertilizer gave the highest number of unfilled grains. Tanaka et al., (1995) and Metwally (2007) reported that the effect of $\mathrm{P}$ application on unfilled grain is mainly attributed to that $\mathrm{P}$ is rapidly deposited in spikelets during the ripening stage. With the progress of ripening, it ultimately accumulates in the form of phytic acid in cellular particles of the aleurone layer. Phytic acid becomes the source of phosphoric acid. Phytic acid function to adjust the concentration of phosphoric acid is utilized for starch synthesis. So, the highest level of phosphorus increases the metabolites stream translocated from source to sink and results in an increase in the maximum number of spikelets and minimizes the number of unfilled grains. The finding of the present 
Table (6): Number of filled grains panicle ${ }^{-1}$ of the Egyptian Hybrid Rice1 variety as affected by the interaction between phosphorus levels and the time of foliar application.

\begin{tabular}{|c|c|c|c|c|}
\hline \multirow{2}{*}{$\begin{array}{r}\mathrm{H}_{3} \mathrm{PO}_{4} \\
\text { foliar }\end{array}$} & \multicolumn{4}{|c|}{2014} \\
\hline & F1 & F2 & F3 & F4 \\
\hline $0 \quad(\mathrm{P} 1)$ & 147.80 & 153.45 & 149.40 & 154.95 \\
\hline 18 (P2) & 160.45 & 167.05 & 161.80 & 165.25 \\
\hline 36 (P3) & 166.75 & 175.70 & 172.45 & 172.80 \\
\hline $54(\mathrm{P} 4)$ & 170.55 & 174.80 & 173.65 & 173.75 \\
\hline LSD $5 \%$ & \multicolumn{4}{|c|}{1.94} \\
\hline
\end{tabular}

F1= without foliar, F2= foliar $2 \% \mathrm{H}_{3} \mathrm{PO}_{4}$ at MT, F3= foliar $2 \% \mathrm{H}_{2} \mathrm{PO}_{4}$ at $\mathrm{LB}$ and $\mathrm{F} 4=$ foliar $2 \% \mathrm{H}_{2} \mathrm{PO}_{4}$ at $\mathrm{MT}+\mathrm{LB}$.

study is in agreement with that of Alam et al. (2009) and Metwally et al. (2012).

The data in Table (5) also showed that foliar spray with $2 \% \mathrm{H}_{3} \mathrm{PO}_{4}$ at $\mathrm{MT}$ in $\mathrm{F} 2$ treatment gave the lowest value of number of unfilled grains which is statistically similar with the value of foliar spray with $2 \% \mathrm{H}_{3} \mathrm{PO}_{4}$ at $\mathrm{MT}+\mathrm{LB}$ stages (F4) in both seasons. Interaction of $\mathrm{P}$ basal treatments and foliar spray with $2 \% \mathrm{H}_{3} \mathrm{PO}_{4}$ at different time of application significantly affected the number of unfilled grain panicle ${ }^{-1}$ in both seasons (Table 7). Application of $54 \mathrm{~kg}$ $\mathrm{P}_{2} \mathrm{O}_{5}$ ha $^{-1}(\mathrm{P} 4)$ combined with $\mathrm{F} 2$ treatment gave the lowest values of unfilled grain panicle ${ }^{-1}$ in both seasons. The highest values of unfilled grain panicle ${ }^{-1}$, however, were obtained by the treatment P1F1 (no P fertilizer was added). A similar trend was found by Zayed (2012).

The data in Table (5) also revealed that basal application of phosphorus or as foliar using $2 \%$ orthophosphoric acid caused an increase in 1000-grain weight as compared with control treatment. The highest 1000-grain weight was observed either with 36 or $54 \mathrm{~kg} \mathrm{P}_{2} \mathrm{O}_{5}$ ha $^{-1}$ in the two studied seasons. Spraying the tested cultivar with $2 \%$ orthophosphoric acid at MT (F2) gave the heaviest 1000-grain weight followed by F4 treatment without any significant difference between them in the two seasons under study. The interaction between $\mathrm{P}$ levels (basal application) and 2\% orthophosphoric acid sprayed at different periods in 1000-grain weight of EHR1 is presented in Table (8). Data revealed that mostly the combination of F2 with each of $\mathrm{P} 3$ and $\mathrm{P} 4$ treatments and the combination of F4 with each of $\mathrm{P} 3$ and $\mathrm{P} 4$ treatments produced the greatest 1000-grain weight, while combination of F1 with P1 gave the least in the two studied seasons. The increase in 1000-grain weight due to the $\mathrm{P}$ applied basally with $\mathrm{P}$ as foliar spray in different periods could be attributed to improvement of rice growth and increased $\mathrm{P}$ content in leaf at growth stages, particularly during reproductive and active grain filling stages, which improves photosynthesis and reaches to maximum assimilates that are translocated rapidly from source to sink and consequently increase the filling of spikelet completely resulted in heavy grains. A similar trend was found by Zayed (2012).

\subsection{Grain and straw yields}

Grain and straw yields of the hybrid rice variety as influenced by the basal application of phosphorus fertilizer and the foliar application with $2 \%$ orthophosphoric acid at different stages are presented in Table (9). Data showed that the application of P either basally or foliar caused an increase in grain yield as compared with control. The greatest value of grain yield was obtained when the cultivar under study was fertilized with $54 \mathrm{~kg} \mathrm{P}_{2} \mathrm{O}_{5} \mathrm{ha}^{-1}$ followed by $36 \mathrm{~kg} \mathrm{P}_{2} \mathrm{O}_{5} \mathrm{ha}^{-1}$ when the $\mathrm{P}$ was applied basally before planting. Shah (2002), Alam et al. (2009), Metwally et al., (2012) and Naeem et al. (2016) also reported a similar response of $\mathrm{P}$ application on grain yield. Data also showed that when application of $\mathrm{P}$ as foliar spray (2\% orthophosphoric acid) at mid tillering (MT) or at both MT + LB (late booting), the grain yield also reached to maximum value as compared with the other spraying treatments. The interaction between phosphorus levels basally and foliar application with $2 \%$ orthophosphoric acid at different periods is presented in Table (10). Data revealed that all the combinations of $\mathrm{P}$ levels with each of foliar spray treatments significantly increased grain yield as compared with control treatment (P1F1). The highest grain yield was obtained when either F2 or F4 was combined with each of P3 and P4 treatments, without any significant differences among them. The combination of F3 (sprayed at late booting) with any of $\mathrm{P}$ levels did not reach to the maximum yield; it might be due to the present of enough amount of phosphorus during filling period and consequently the response of plant at this time to $\mathrm{P}$ was very low. The increases of grain yield under P3 and P4 or with combination of either F2 and F3 with both P3 and $\mathrm{P} 4$ could be attributed to adequate enough of $P$ as energetic elements that increases the biological processes (ATP, NAD and NADP) which leads to supply all the chemical compounds by energy inside the plant beside the improvement of physiological processes such 
Table (7): Number of unfilled grains panicle ${ }^{-1}$ of the Egyptian Hybrid Rice1 variety as affected by interaction between phosphorus levels and time of foliar application.

\begin{tabular}{|c|c|c|c|c|c|c|c|c|}
\hline \multirow{2}{*}{$\begin{array}{r}\mathrm{H}_{3} \mathrm{PO}_{4} \text { foliar } \\
\mathrm{P}_{2} \mathrm{O}_{5} \mathrm{~kg} \mathrm{ha}^{-\mathrm{T}}\end{array}$} & \multicolumn{4}{|c|}{2014} & \multicolumn{4}{|c|}{2015} \\
\hline & F1 & F2 & F3 & F4 & F1 & F2 & F3 & F4 \\
\hline $0 \quad(\mathrm{P} 1)$ & 17.20 & 12.75 & 16.50 & 14.17 & 15.07 & 11.80 & 14.52 & 11.80 \\
\hline $18(\mathrm{P} 2)$ & 15.85 & 13.60 & 13.95 & 13.15 & 14.64 & 11.60 & 13.05 & 11.17 \\
\hline 36 (P3) & 14.90 & 11.80 & 14.60 & 11.80 & 12.77 & 10.92 & 12.03 & 11.98 \\
\hline $54(\mathrm{P} 4)$ & 12.80 & 10.75 & 11.75 & 11.55 & 11.30 & 9.99 & 10.87 & 10.53 \\
\hline LSD $5 \%$ & \multicolumn{4}{|c|}{1.17} & \multicolumn{4}{|c|}{0.65} \\
\hline
\end{tabular}

F1= without foliar, $\mathrm{F} 2=$ foliar $2 \% \mathrm{H}_{3} \mathrm{PO}_{4}$ at $\mathrm{MT}$, F3= foliar $2 \% \mathrm{H}_{3} \mathrm{PO}_{4}$ at $\mathrm{LB}$ and $\mathrm{F} 4=$ foliar $2 \% \mathrm{H}_{3} \mathrm{PO}_{4}$ at MT+LB.

Table (8): Weight of 1000-grain the Egyptian Hybrid Rice1 variety as affected by interaction between phosphorus levels and time of foliar application.

\begin{tabular}{|c|c|c|c|c|c|c|c|c|}
\hline \multirow{2}{*}{$\begin{array}{l}\mathrm{H}_{3} \mathrm{PO}_{4} \text { foliar } \\
\mathrm{P}_{2} \mathrm{O}_{5} \mathrm{~kg} \mathrm{ha}^{-}\end{array}$} & \multicolumn{4}{|c|}{2014} & \multicolumn{4}{|c|}{2015} \\
\hline & F1 & F2 & F3 & F4 & F1 & $\mathbf{F} 2$ & F3 & F4 \\
\hline $0 \quad(\mathrm{P} 1)$ & 24.07 & 24.34 & 24.11 & 24.28 & 24.15 & 24.45 & 24.30 & 24.50 \\
\hline 18 (P2) & 24.35 & 24.96 & 24.47 & 25.06 & 24.58 & 25.12 & 24.83 & 25.17 \\
\hline 36 (P3) & 25.08 & 26.08 & 25.28 & 25.68 & 25.23 & 26.02 & 25.29 & 25.73 \\
\hline $54(\mathrm{P} 4)$ & 25.30 & 25.65 & 25.32 & 25.74 & 25.28 & 25.72 & 25.36 & 25.79 \\
\hline LSD $5 \%$ & \multicolumn{4}{|c|}{0.50} & \multicolumn{4}{|c|}{0.64} \\
\hline
\end{tabular}

F1= without foliar, F2= foliar $2 \% \mathrm{H}_{3} \mathrm{PO}_{4}$ at MT, F3= foliar $2 \% \mathrm{H}_{3} \mathrm{PO}_{4}$ at $\mathrm{LB}$ and $\mathrm{F} 4=$ foliar $2 \% \mathrm{H}_{3} \mathrm{PO}_{4}$ at MT+LB.

Table (9): Grain, straw yields and phosphorus uptake $\mathrm{kg} \mathrm{ha}^{-1}$ of the Egyptian Hybrid Rice1 variety as affected by phosphorus levels and time of foliar application.

\begin{tabular}{|c|c|c|c|c|c|c|}
\hline \multirow[t]{2}{*}{ Treatment } & \multicolumn{2}{|c|}{ Grain yield t ha ${ }^{-1}$} & \multicolumn{2}{|c|}{ Straw yield $\mathrm{t} \mathrm{ha}^{-1}$} & \multicolumn{2}{|c|}{$\begin{array}{c}\text { P uptake } \mathrm{kg} \mathrm{ha}^{-1} \text { by } \\
\text { biological yield }\end{array}$} \\
\hline & 2014 & 2015 & 2014 & 2015 & 2014 & 2015 \\
\hline P level ( basal) & & & & & & \\
\hline control (P1) & 9.75 & 9.80 & 12.63 & 13.53 & 26.76 & 27.11 \\
\hline $18 \mathrm{~kg} \mathrm{P}_{2} \mathrm{O}_{5} \mathrm{ha}^{-1}(\mathrm{P} 2)$ & 10.28 & 10.55 & 13.22 & 13.92 & 30.05 & 30.60 \\
\hline $36 \mathrm{~kg} \mathrm{P}_{2} \mathrm{O}_{5} \mathrm{ha}^{-1}(\mathrm{P} 3)$ & 11.13 & 11.12 & 14.48 & 14.49 & 35.91 & 34.54 \\
\hline $54 \mathrm{~kg} \mathrm{P}_{2} \mathrm{O}_{5} \mathrm{ha}^{-1}(\mathrm{P} 4)$ & 11.40 & 11.29 & 14.92 & 14.86 & 37.64 & 36.22 \\
\hline LSD 5\% & 0.25 & 0.11 & 0.33 & 0.24 & 0.44 & 0.30 \\
\hline $\mathrm{H}_{3} \mathbf{P O}_{4}$ foliar spray & & & & & & \\
\hline Without (F1) & 10.29 & 10.12 & 13.06 & 13.69 & 29.92 & 28.92 \\
\hline $2 \%$ at $\mathrm{MT}(\mathrm{F} 2)$ & 10.92 & 11.09 & 14.12 & 14.38 & 33.81 & 33.82 \\
\hline $2 \%$ at $\mathrm{LB}(\mathrm{F} 3)$ & 10.43 & 10.48 & 13.71 & 14.15 & 31.84 & 31.27 \\
\hline $2 \%$ at $\mathrm{MT}+\mathrm{LB}(\mathrm{F} 4)$ & 10.93 & 11.07 & 14.36 & 14.59 & 34.77 & 34.57 \\
\hline LSD 5\% & 0.22 & 0.10 & 0.29 & 0.27 & 0.45 & 0.20 \\
\hline Interaction & $*$ & $*$ & $*$ & $*$ & $* *$ & $* *$ \\
\hline
\end{tabular}

MT=Mid tillering $\quad$ LB= Late booting

Table (10): Grain yield $\mathbf{t} \mathrm{ha}^{-1}$ of the Egyptian Hybrid Rice1 variety as affected by interaction between phosphorus levels and time of foliar application.

\begin{tabular}{|c|c|c|c|c|c|c|c|c|}
\hline \multirow{2}{*}{$\mathrm{P}_{2} \mathrm{O}_{5} \mathrm{~kg} \mathrm{ha}^{-\mathrm{H}}$} & \multicolumn{4}{|c|}{2014} & \multicolumn{4}{|c|}{2015} \\
\hline & F1 & F2 & F3 & F4 & F1 & F2 & F3 & F4 \\
\hline $0 \quad(\mathrm{P} 1)$ & 9.42 & 9.89 & 9.64 & 10.03 & 9.30 & 10.10 & 9.66 & 10.15 \\
\hline $18(\mathrm{P} 2)$ & 9.94 & 10.55 & 10.06 & 10.57 & 10.06 & 10.88 & 10.46 & 10.80 \\
\hline $36(\mathrm{P} 3)$ & 10.74 & 11.54 & 10.84 & 11.40 & 10.46 & 11.57 & 10.80 & 11.65 \\
\hline $54(\mathrm{P} 4)$ & 11.05 & 11.68 & 11.18 & 11.70 & 10.67 & 11.79 & 11.01 & 11.70 \\
\hline LSD $5 \%$ & \multicolumn{4}{|c|}{0.44} & \multicolumn{4}{|c|}{0.32} \\
\hline
\end{tabular}

F1 = without foliar, F2= foliar $2 \% \mathrm{H}_{3} \mathrm{PO}_{4}$ at MT, F3= foliar $2 \% \mathrm{H}_{3} \mathrm{PO}_{4}$ at $\mathrm{LB}$ and F4= foliar $2 \% \mathrm{H}_{3} \mathrm{PO}$ at MT+LB. 
as photosynthesis due to increase in the viability of flag leaf (late the senescence of flag leaf) and second plus third leaf which represent about $75 \%$ from the total photosynthesis during filling period. The highest amount of metabolites produced of high photosynthesis, that are directly translocated to the panicles and completely fill the highest number of the spikelets of the large panicle of hybrid rice and consequently increases the number of filled panicles, weight of panicle, number of filled grains resulting in an increase of the grain yield. Choudhury et al. (2007) reported that P applied during the tillering stage is most efficiently utilized for grain production. These results are in agreement with Zayed (2012), who reported that
Foliar spray with $2 \% \quad \mathrm{H}_{3} \mathrm{PO}_{4}$ at the period of $\mathrm{MT}+\mathrm{LB}(\mathrm{F} 4)$ gave the maximum straw yield which was statistically similar with the treatment F2 in both seasons. The lowest straw yield was recorded with control.

Interaction between $\mathrm{P}$ basal treatments and foliar spray with $2 \% \mathrm{H}_{3} \mathrm{PO}_{4}$ at different growth stages significantly affected the straw yield in both seasons (Table 11). Application of $54 \mathrm{~kg}$ $\mathrm{P}_{2} \mathrm{O}_{5}$ ha $^{-1}(\mathrm{P} 4)$ coupled with $\mathrm{F} 4$ treatment gave the highest value of straw yield which was statistically similar to the values of P3F4 and P4 $\mathrm{F} 2$ treatments in the first season and with $\mathrm{P} 2 \mathrm{~F} 4$ in the second season. The lowest values of straw yield, however, were obtained by the treatment P1 F1 (no P fertilizer was added).

Table (11): Straw yield $t$ ha $^{-1}$ of the Egyptian Hybrid Rice1 variety as affected by interaction between phosphorus levels and time of foliar application.

\begin{tabular}{|c|c|c|c|c|c|c|c|c|}
\hline \multirow{2}{*}{$\begin{array}{l}\mathrm{H}_{3} \mathrm{PO}_{4} \text { foliar } \\
\mathrm{P}_{2} \mathrm{O}_{5} \mathrm{~kg} \mathrm{ha}^{-\mathrm{T}}\end{array}$} & \multicolumn{4}{|c|}{2014} & \multicolumn{4}{|c|}{2015} \\
\hline & F1 & F2 & F3 & F4 & F1 & F2 & F3 & F4 \\
\hline $0 \quad(\mathrm{P} 1)$ & 11.93 & 12.95 & 12.59 & 13.05 & 12.72 & 13.84 & 13.62 & 13.95 \\
\hline $18(\mathrm{P} 2)$ & 12.63 & 13.66 & 12.80 & 13.79 & 13.24 & 14.08 & 13.92 & 14.44 \\
\hline $36(\mathrm{P} 3)$ & 13.61 & 14.62 & 14.58 & 15.13 & 14.29 & 14.50 & 14.38 & 14.80 \\
\hline $54(\mathrm{P} 4)$ & 14.10 & 15.23 & 14.89 & 15.46 & 14.50 & 15.07 & 14.67 & 15.18 \\
\hline LSD $5 \%$ & \multicolumn{4}{|c|}{0.44} & \multicolumn{4}{|c|}{0.37} \\
\hline
\end{tabular}

F1= without foliar, F2= foliar $2 \% \mathrm{H}_{3} \mathrm{PO}_{4}$ at MT, F3= foliar $2 \% \mathrm{H}_{3} \mathrm{PO}_{4}$ at $\mathrm{LB}$ and $\mathrm{F} 4=$ foliar $2 \% \mathrm{H}_{3} \mathrm{PO}_{4}$ at MT+LB.

both of early $\mathrm{P}$ application via root medium and $\mathrm{P}$ application via foliage were effective for considerable rice grain yield. Doberman and Fairhruse (2000) reported that $\mathrm{P}$ is remobilized within the plant during later growth stages if sufficient $\mathrm{P}$ has been absorbed during early growth.

Straw yield increased linearly with increment of fertilizer levels of phosphorus up to $54 \mathrm{~kg} \mathrm{P}_{2} \mathrm{O}_{5}$ (Table 9). In both seasons, the highest values of straw yield were recoded when the plants were fertilized at the rate of $54 \mathrm{~kg}$ $\mathrm{P}_{2} \mathrm{O}_{5}$ ha $^{-1}$, while the lowest straw yield was obtained when no $\mathrm{P}$ fertilizer as a basal was added. High straw yield with increase levels of $P$ basal application might be due to the increase in growth, i.e. plant height and the number of tillers (plant canopy). These findings are in close agreement with Tang and $\mathrm{Yu}$ (2002) and Metwally et al. (2012), who reported that the increase in straw yield with $\mathrm{P}$ fertilizer might be due to the increase in vegetative growth due to enhancement of cell division and elongation in stem internodes. Straw yield of EHR1 was also significantly increased due to application of $\mathrm{P}$ as foliar spray at different growth stages (Table 9).

\subsection{Phosphorus uptake $\left(\mathrm{kg} \mathrm{ha}^{-1}\right)$}

Phosphorus uptake by biological yield (grain and straw yields) was differed significantly among $\mathrm{P}$ basal application, time of foliar application and their interaction in 2014 and 2015 seasons (Table 9). Phosphorus uptake by biological yield significantly increased as $\mathrm{P}$ fertilizer level increased up to $54 \mathrm{~kg} \mathrm{P}_{2} \mathrm{O}_{5} \mathrm{ha}^{-1}$. The greatest $\mathrm{P}$ uptake was observed when the tested cultivar received $54 \mathrm{~kg} \mathrm{P}_{2} \mathrm{O}_{5} \mathrm{ha}^{-1}$, while the lowest value was found when the cultivar did not receive any $\mathrm{P}$ fertilizer. These results are holding true in the two studied seasons. It could be attributed to presence of high available $\mathrm{P}$ in the soil, under the highest level of $P$ fertilizer which caused increases in $\mathrm{P}$ uptake by rice plants besides increasing the biological yield by increasing the levels of $\mathrm{P}$ basal application as compared with unfertilized treatment. A similar trend was found by Gewaily et al. (2011) and Naeem et al. (2016). The data in Table (9) also showed that phosphorus uptake by EHR $1 \mathrm{cv}$. was also significantly increased due to application of $\mathrm{P}$ as foliar spray at different growth stages. Foliar spray with $2 \% \mathrm{H}_{3} \mathrm{PO}_{4}$ at $\mathrm{MT}+\mathrm{LB}$ periods in F4 treatment gave the 
Table (12): Phosphorus uptake $\mathrm{kg} \mathrm{ha}^{-1}$ of the Egyptian Hybrid Rice1 variety as affected by phosphorus levels and time of foliar application.

\begin{tabular}{|c|c|c|c|c|c|c|c|c|}
\hline \multirow{2}{*}{$\begin{array}{r}\mathrm{H}_{3} \mathrm{PO}_{4} \text { foliar } \\
\mathrm{P}_{2} \mathrm{O}_{5} \mathrm{~kg} \mathrm{ha}^{-\mathrm{T}}\end{array}$} & \multicolumn{4}{|c|}{2014} & \multicolumn{4}{|c|}{2015} \\
\hline & F1 & F2 & F3 & F4 & F1 & F2 & F3 & F4 \\
\hline $\begin{array}{ll}0 & (\mathrm{P} 1) \\
\end{array}$ & 25.06 & 27.37 & 26.34 & 28.26 & 25.14 & 28.22 & 26.76 & 28.74 \\
\hline 18 (P2) & 28.14 & 30.91 & 28.76 & 32.37 & 28.10 & 31.62 & 30.10 & 32.61 \\
\hline 36 (P3) & 32.70 & 37.84 & 34.95 & 38.17 & 30.65 & 36.41 & 33.45 & 37.64 \\
\hline $54(\mathrm{P} 4)$ & 33.80 & 39.11 & 37.33 & 40.30 & 31.79 & 39.00 & 34.78 & 39.30 \\
\hline LSD $5 \%$ & \multicolumn{4}{|c|}{0.34} & \multicolumn{4}{|c|}{0.93} \\
\hline
\end{tabular}

F1= without foliar, F2= foliar $2 \% \mathrm{H}_{3} \mathrm{PO}_{4}$ at MT, F3= foliar $2 \% \mathrm{H}_{3} \mathrm{PO}_{4}$ at $\mathrm{LB}$ and F4= foliar $2 \% \mathrm{H}_{3} \mathrm{PO}$ at MT+LB.

maximum phosphorus uptake in both seasons. The lowest phosphorus uptake was obtained with control. Interaction between $\mathrm{P}$ as basal application and foliar spray with $2 \% \mathrm{H}_{3} \mathrm{PO}_{4}$ at different growth periods positively affected the $\mathrm{P}$ uptake in both seasons (Table 12). Application of $54 \mathrm{~kg} \mathrm{P}_{2} \mathrm{O}_{5} \mathrm{ha}^{-1}$ (P4) coupled with F4 treatment produced the highest values of $\mathrm{P}$ uptake in the both seasons. The lowest values of $\mathrm{P}$ uptake, however, were obtained by the treatment P1 F1 (no P fertilizer was added). A similar trend was found by Zayed (2012) who reported that $\mathrm{P}$ application either as basal or foliar spray encourages rice growth involving shoots and root systems resulting in high capability for $\mathrm{P}$ uptake especially under more available $\mathrm{P}$ in the soil.

\section{Conclusion}

According to the previous results, it could be concluded that 1-The Hybrid Egyptian Rice 1 variety responded to phosphorus fertilizer up to $54 \mathrm{P}_{2} \mathrm{O}_{5} \mathrm{~kg} \mathrm{ha}^{-1}$ and produces the greatest yield.

2-Spraying the Egyptian Rice Hybrid 1 variety with $2 \%$ orthophosphoric acid at MT period improved the yield and its components.

3-The combination of 2\% orthophosphoric acid as foliar spray at MT period with either 54 or $36 \mathrm{P}_{2} \mathrm{O}_{5} \mathrm{~kg} \mathrm{ha}^{-1}$ improves most of yield components and produces the same highest grain yield.

4-From the economic point of view, only application of $36 \mathrm{P}_{2} \mathrm{O}_{5} \mathrm{~kg} \mathrm{ha}^{-1}$ combined with $2 \%$ orthophosphoric acid at MT period was the best treatment which caused an improve in plant growth, yield component and gave the greatest grain yield as well as saving 18 $\mathrm{P}_{2} \mathrm{O}_{5} \mathrm{~kg} \mathrm{ha}^{-1}$ which equals $120 \mathrm{~kg}$ single super phosphate $\left(15 \% \mathrm{P}_{2} \mathrm{O}_{5}\right)$ per ha or $50 \mathrm{~kg}$ single super phosphate per fadden. In other words, it saved one third of recommended dose of $\mathrm{P}$ fertilizer.

\section{REFERENCES}

Alam M. M., Ali M.H., Ruhul Amin A.K. M. and Mirza H. (2009). Yield attributes, yield and harvest index of three irrigated rice varieties under different levels of phosphorus. Adv. Biolo. Res., 3 (3-4): 132-139.

Barker A. V. and Pilbeam D.J.(2007). Handbook of Plant Nutrition. CRC Press Taylor and Francis Group, Broken Sound Parkway, Boca Raton, U.S.A. PP 81.

Brady N.C. and Weil R. R. ( 2002). The nature and properties of soils, $13^{\text {th }}$ edition. Prentice Hall Upper Saddle River, NJ:.

Cahyono O. and Hartati S. (2013). Improvement of phosphate fertilization method in wetland rice. Agrivita, 35 (1): 81-87.

Choudhury A. T. M., Kennedy I. R. Ahmed M. F. and Kecskes M. L (2007). Phosphorus fertilization for rice and control of environment pollution problems. Pak. Biolo. Sci., 10 (13):2098-2105.

Doberman A. and Fairhruse T. H. (2000). Rice nutrient disorder and nutrient management. International Rice Research Institute (IRRI), MCPO Box 3127 ,Philippines.

Epstein E. and Bloom A. J. (2005). Mineral nutrition of plants: Principles and perspectives. Sinauer Associates Sunderland, Massachusetts, , Inc. Pub USA.

Fageria N.K. and Baligar V.C.(2001). Improving nutrient use efficiency of annual crops in Brazilian acid soils for sustainable crop production. Commune Soil Sci. Plant Anal., 32:1303-1319.

Fageria N. K. and Baligar V.C. (2005). Nutrient availability. In: Encyclopedia of soils in the environment, D. Hillel, (Ed.),PP. 6371. Elsevier. San Diego, CA: 
Faye I., Diouf O., Guisse A., Sene M. and Diallo N. (2006). Characterizing root responses to low phosphorus in pearl millet (Pennisetum glaucum L. R. Br.). Agron. J., 98:1187-1194.

Gewaily E. E. Naeem E.S., Metwally T. F. and Nasr El-Din I.E. (2011). Availability of some nutrients and rice yield as affected by rice straw fertilization under continuous flooding and saturation. J. Soil Sci. and Agric. Eng., Mansoura Univ., 2 (3): $379-392$.

Girma K., Martin K. L., Freeman K. W., Mosali J., Teal R. K., Raun W., Moges R. S. M. and Arnall D. B. (2007). Determination of optimum rate and growth for foliar applied phosphorus in corn. Commune Soil Sci. Plant Anal., 38: 1137-1154.

Gomez K.A. and. Gomez A. A. (1984). Statistical Procedures for Agricultural Research. $2^{\text {nd }}$ ed. John Wiley Sons, New York, USA.

Higgs B., Johnston A. E., Salter J. L. and Dawson C. J. (2000). Some aspects of achieving sustainable phosphorus use in agriculture. J. Environ. Qual., 29: 80-87.

Matsou T., Kumazawa K., Ishii R., Ishihara K. and Hirata H. (1995). Science of the plant physiology. Food and Agriculture Policy Research Center, Tokyo, Japan, 2: 1240.

Metwally T. F. (2007). Performance of Sakha 104 rice cultivar as affected by the interaction between $\mathrm{Zn}, \mathrm{N}, \mathrm{P}$ and $\mathrm{K}$ fertilizer. Ph. D. Thesis, Agron. Dept., Fac. Agic., Karf El-Sheish Unvi., Egypt.

Metwally T. F., El-Rewainy I. M. and Sedeek S. E. M. (2012). Performance of different rice genotypes under application of phosphorus fertilizer levels. J. Plant Produc., Mansoura Univ., 3 (3): 427-444.
Naeem E. S., Metwally T. F., Hashem I. M. and Abd El-Mgeed T. M. (2016). Phosphorus fertilization requirement for rice under clayed alkaline soils. J. Plant Production, Mansoura Univ., 7 (2): 161-168.

Sahar A. and Burbey N. (2003). Effect of nitrogen, phosphorus and potassium (N P $\mathrm{K})$ compound dosages on the growth and yield of lowland rice. J.Stigma, Indonesia, 11(1): 26-29.

Shah M. A. L. (2002). Phosphorus nutrition of rice varieties in relation to phosphorus sources and rates on a phosphorus deficit Soil. Ph.D. Thesis Dep. Soil Sci. Banghabandhu, Seikh Mujibur Rahman. Agri. Univ, Gazipur, Bangladesh.

Slaton N. A., Wilson C.E., Norman J. R..J., Ntamatungiro S. and Frizzell D. L. (2002). Rice response to phosphorus fertilizer application rate and timing on alkaline soils in Arkansas. Agro.J. 94: 1393-1399.

Tang X. R. and Yu T. Q. (2002). Effects and mechanisms of $\mathrm{P}$ and $\mathrm{K}$ nutrients on yield and protein content of fodder rice. Agric. Sci. in China, 1(14): 432-437.

Tanaka K., Kasai Z. and Ogawa M. (1995). Physiology of Ripening. Science of the Rice Plant. Physiology, Food and Agric. Polic Res. Center,Tokyo. Japan. 2: 97118.

Watanabe F.S. and Olsen S.A. (1965). Calorimetric determination of phosphorus in water extract of soil. Soil Sci., 93: 183188.

Zayed B. A. (2012). The role of phosphorus management in salinity tolerance alleviation in rice crop. Egypt. J. Agric. Res., 90 (2): 667-685. 


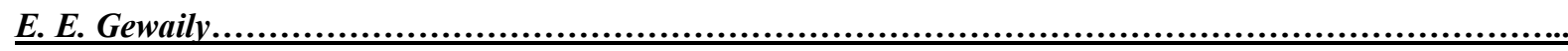

أداء صنف الأرز هجين مصرى واحد تحت مستويات مختلفة من السماد الفوسفاتى والرش بحامض الارثوفوسفوريك

السيد السيد جويلى

مركز بحوث وتدريب الأرز - معهد بحوث المحاصيل الحقلية ـ مركز البحوث الزر اعيةـ سخا ـ كفر الثيخ ـ مصر

ملخص

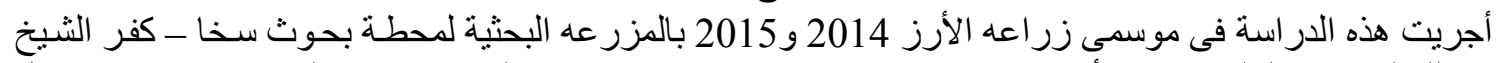

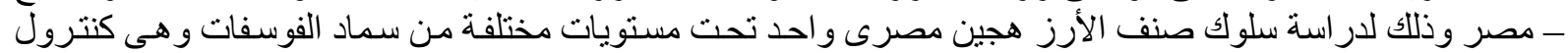

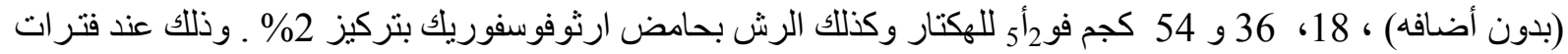

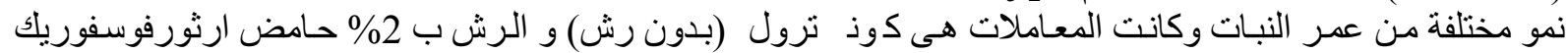

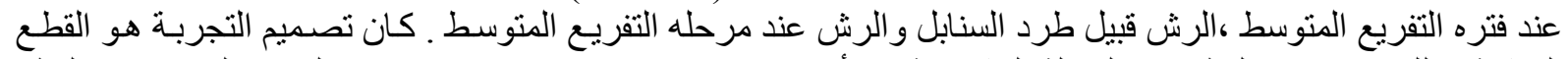

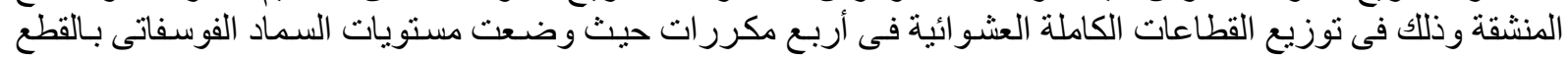

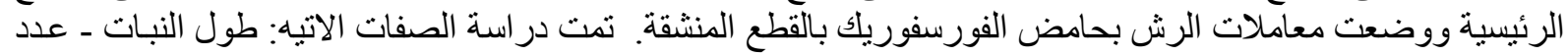

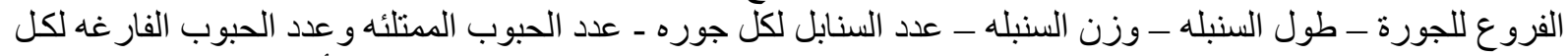

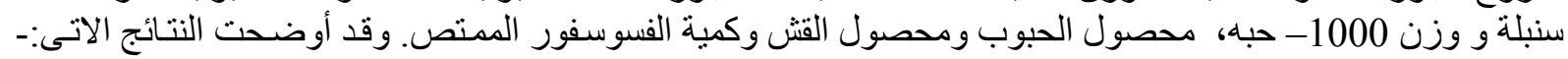

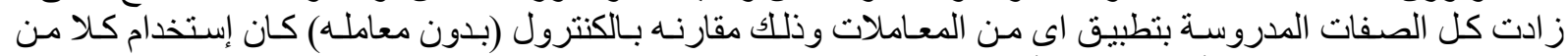

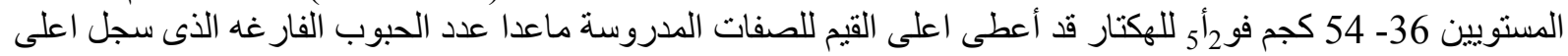

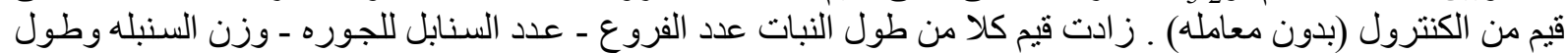

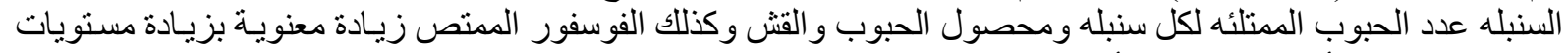

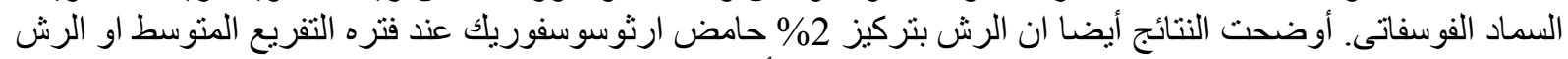

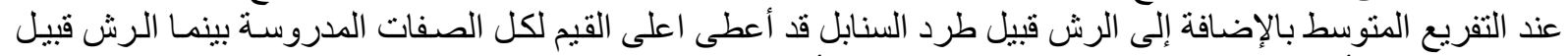

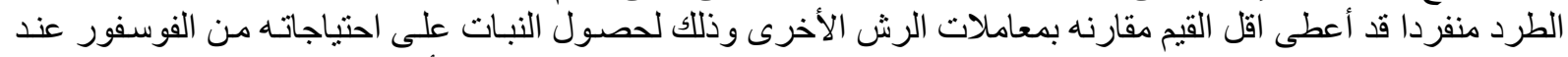

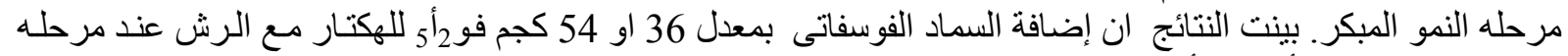

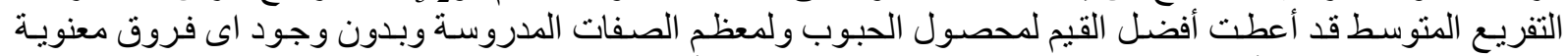

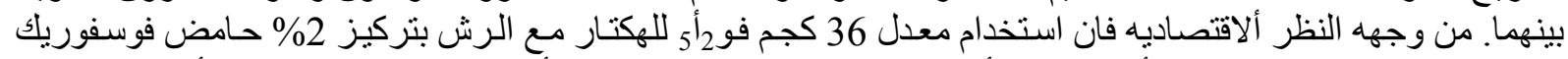

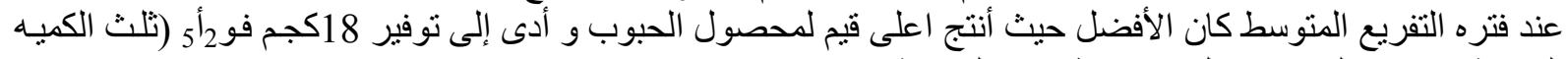

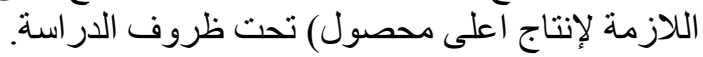

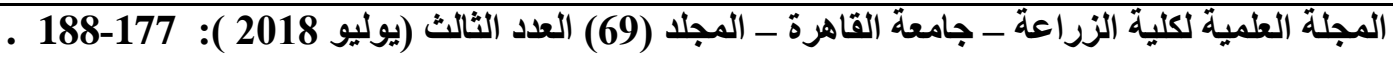

